\title{
FEMALE PERCEPTIONS ON EMPLOYMENT EQUITY: IS THE GLASS CEILING CRACKING?
}

\author{
BETSI VAN ZYL \\ GERT ROODT \\ Department of Human Resources Management \\ RAU University
}

\begin{abstract}
The primary objective of this study was to assess if there were any perceptual differences between gender groups regarding employment equity practices. A sample of 4729 participants from different companies and industries completed the Employment Equity Questionnaire. Results from an ANOVA indicated that there were significant differences between gender groups, but only a small portion of the variance was explained by perceptual differences on employment equity practices. The instrument thus possesses some discriminant validity. Further analyses on an item level indicated that there were significant differences between gender groups, but these differences were not attributable to gender stereotypes. Specific employment equity practices were identified that need closer attention from management's side to address gender discrimination.
\end{abstract}

\section{OPSOMMING}

Die primêre doelwit van hierdie studie was om vas te stel of daar enige perseptuele verskille tussen geslagsgroepe bestaan ten opsigte van werkgelykheidspraktyke. 'n Steekproef van 4729 deelnemers uit verskillende ondernemings en bedrywe het die Employment Equity Questionnaire voltooi. Die resultate van 'n ANOVA het aangedui dat daar beduidende verskille tussen geslagsgroepe bestaan, maar dat slegs 'n klein gedeelte van die variansie aan perseptuele verskille ten opsigte van werksgelykheidspraktyke toegeskryf kan word. Die instrument beskik dus ook 'n mate van diskriminante geldigheid. Verdere ontledings op itemvlak het aangedui dat daar betekenisvolle verskille tussen geslagsgroepe is, maar dat hierdie verskille nie aan geslagstereotipes toegeskryf kan word nie. Spesifieke werkgelykheidspraktyke is geïdentifiseer wat nadere aandag deur die bestuurskader verdien om geslagsdiskriminasie aan te spreek.

\begin{abstract}
"...While women are becoming more important in the business world, very few are holding truly top level jobs" (Ellman, 1963). It seemed that concerns about gender fairness in employment had been a debated issue since the sixties as indicated by the above quote. Previous studies indicated that men were holding pivotal positions in organisations (corporate board seats) and that women occupied positions of less influence, lower status and lower pay (Humphries \& Grice, 1996; Jackson, 2001). Several measures were designed in an attempt to rectify inequalities.
\end{abstract}

\section{Measures to address gender inequality}

Legislative intervention such as equal employment opportunity (EEO) and Affirmative Action (AA) policies were introduced in various countries across the globe to address this issue about fairness and discrimination in the workplace. However, it seemed, that inequality still persisted (Humphries \& Grice, 1995). Mavin (2001) argued that male career models and approaches remained, and that women were being disadvantaged when they stepped out to meet family responsibilities. Women were subtly forced to choose between upward mobility in career and family stability in the home, or even a family at all. Now if this problem existed from the sixties up to the twenty-first century and there was supportive legislation to abolish it, it would be a pertinent issue especially for an emerging market such as South Africa.

Employment Equity Legislation, internationally and nationally, endeavored to ensure the equitable representation of women and other designated groups in all occupational categories and levels in the workplace (Thomas, 2002). Within these legislation and connecting literature various concepts were being used constantly. It should be useful to investigate what equal employment opportunity encompassed.

Employment Equity was seen as a long-term programme to ensure that all employees have a fair chance in the workplace. It would be achieved when no person is denied employment

Requests for copies should be addressed to: B van Zyl, Department of Human Resource Management, RAU University, PO Box 524, Auckland Park, 2006 opportunities or benefits for reasons unrelated to their abilities (Thomas, 2002, Toumishey, 2001). Affirmative action was seen as a short-term strategy by which equality (employment equity) in the workplace would be achieved through the active elimination of systemic discrimination (Thomas, 2002, Toumishey, 2001). Systemic Discrimination occurred when groups of people, e.g. women were excluded from the workplace for reasons not related to job requirements. It resulted from entrenched policies/practices that were part of the normal operation of employment systems that unintentionally discriminated (Toumishey, 2001). Human (1996) saw Affirmative Action as the process whereby equal employment equity was created - cutting across all human resources practices such as selection, recruitment, induction, development, etc. This referred to a more holistic focus such as diversity management.

Diversity management was a planned, systematic and comprehensive managerial process for developing an organisational environment in which all employees, with their similarities and differences, could contribute to the strategic and competitive advantage of the organisation, and where no-one was excluded on the basis of factors unrelated to productivity (Thomas, 1997). Both Affirmative Action and diversity management should lead to equal employment opportunities, which was the ultimate goal. Diversity in its fullest sense involved a broad range of human uniqueness -- personality, work style, perception and attitudes, values and lifestyle, work ethic, worldview and communication style. Dickens (1994) who called it a holistic approach also supports this view of diversity management. However, she also emphasised that most diversity pogrammes focused on valuing ethnic and cultural diversity and not so much gender. Mallon and Cassell (1999) also stated that diversity management approaches moved beyond the limited remedial aspirations of traditional equal opportunities policies. The approach was about enhancing the contribution of each member of an organisation and creating an inclusive culture, the stimulus being business need rather than social justice.

The next section provides a broad overview on international trends regarding gender equality. 
Some international trends on gender equality

What had legislation achieved so far? The 1964 the Civil Rights Law in the USA was amended and strengthened in the Equal Employment Opportunities Act in 1972. This act set up the Equal Employment Opportunities Commission (EEOC) which in turn set up the Affirmative Action Plan. The Affirmative Action Plan had made a significant impact on the progress of women at work, although it was not a guarantee against indirect forms of discrimination. It seems that the USA has had success with their legislation, but Thomas (2002) pointed out that the focus had been on numbers. Meyerson and Fletcher (2000) indicated that women at the highest levels of business were rare. Fortune 500 companies only boasted with $10 \%$ women at senior management level. Less than $4 \%$ of CEO's/presidents were female and less than 3\% of top corporate earners. Burke and Mattis (2000) supported this. They stated that in 1998/1999 there were only two women Fortune 500 CEO's. In the USA in 1998 only a little more than $10 \%$ of women held board seats.

Currently there is a movement to abolish affirmative action because it is believed that the policy is counter-productive and not useful anymore (Thomas, 2002). In Canada 1996, the Canadian Minister of Labour (Alfonso Gagliano) announced the new Employment Equity Act and Regulations. This act brought about changes to the Employment Equity Act of 1986. It strengthened previous employment equity law by clarifying employer's responsibilities and giving the Canadian Human Rights Commission the authority to ensure compliance. Thomas (2002) indicated that the first legislation did little to eliminate discriminatory policies and procedures and that the new legislation focused more on barriers to employment equity, organisational culture and systemic discrimination (including policies and procedures). In 1997 70\% of corporate boards still did not have any female representation and only $6 \%$ of women were involved at top level. Singh and Sturges in Burke and Mattis (2000) stated that women and men also tend to occupy different managerial jobs, e.g. women in more "specialist" support roles such as marketing or personnel and men more in generalist positions that generally had higher status than support roles.

An Equal Pay Act was introduced in the UK in 1970. In 1984 equal pay for work of equal value amendments were introduced. Unfortunately the Equal Pay (Amendment) Regulations 1984 had many loopholes. It had little effect on pay disparities between men and women. The average gross weekly earnings had only risen from $65 \%$ to $76,6 \%$ of men's wages between 1970-1990. Thomas (2002) indicated that the legislation in the UK was fragmentary and confusing. In UK in 1996 only 3,3\% of directors were women and only in a non-executive capacity (Burke \& Mattis, 2000). In the UK a two million rise in the number of women in work corresponded with a 2,8 million fall in the number of men. However, women still earned considerably less than men and were under represented at the higher levels of organisations (Cassell, 1996). According to Dickens (1994) women's full-time gross weekly earnings amounted to $71,5 \%$ of that of men; hourly earnings were $78,9 \%$ of that of men. In terms of total remuneration packages women were disadvantaged in having less access to benefits such as companyprovided healthcare, pensions, company cars, etc. Women in management positions received two-thirds of the average weekly earnings of male counterparts.

In New Zealand an Equal Pay Act with the objective of pay equity for women was promulgated in 1972 as well as a Human Rights Commission Act in 1977 with the objective of equal employment opportunities for women. Both of these acts led to the Employment Equity Act of 1990. In Australia and New Zealand in 1997 there were only 4\% of women on corporate boards. This act was repealed in 1999. It was found to be inconsistent. In the same year the Employment Contacts Act was introduced and the principles of free market were applied to people. This act put the focus on individual contracts of employment and not historical arbitration to set wages. Under the new contract women were able to negotiate and enforce contracts that suited their individual and family circumstances (Humphries \& Grice, 1995). The next section takes a closer look at gender equality in the South African context.

\section{South African trends on gender equality}

The Constitution of South Africa guaranteed everyone the fundamental right of equality. The elimination of unfair discrimination and the adoption of positive measures to redress social imbalances were important components of this process and thus the Employment Equity Act was a necessary step towards the achievement of the constitutional goals. The Employment Equity Act was incrementally promulgated into law in 1999.

Human (1996) indicated that South African organisations were also playing the numbers game. They did not realise that affirmative action is the process of creating equal employment opportunity and that it required fundamental changes to the human resource culture. Human (1996) argued that affirmative action/employment equity both encompassed, and were encompassed by, the concept of managing diversity. Women marched to the Union Buildings in 1956 and they sang a song. "Wathint' Abafazi, Wathint' Imbokotho, Uzakufa!" Translated it means you have tampered with the women. You have struck a grinding stone. The Minister of Labour said that the Employment Equity Act gave the women another grinding stone - another powerful tool. According to him the Act was a pledge to spare no effort in the struggle for gender equity (Mdladlana, 1999a). On 29 July 1999 Steve Tshwete (at a function to launch Affirmative Action Programme in the Police Force) made the following comment: "We do not only want to see leaders emerging from the male section. We want to see women being given positions in the command structures". He also said that South Africa has not yet arrived - where men and women were treated equally (Mdladlana, 1999b). Of the economically active population (EAP) women comprised $39,85 \%$, and only $27,45 \%$ of management. Thomas (2002), using the Breakwater Monitor results of 1998 indicated a lower percentage - only 14\% of managers are women.

Human (1996) indicated that in South Africa, which has a strong patriarchial attitude, male managers doubted the business abilities of women. These attitudes led to practices, which inherently put women at a disadvantage through deeply entrenched stereotyping of gender. According to a report released in 1999 by the Gender Commission, most companies preferred employing men to women because of a lack of gender policy, lack of trust in women, cultural views and resistance by male employees (Mdladlana, 1999a). The report also indicated a variance in income between men and women, for the same job. Thomas (2002) supported this viewpoint by indicating that male wages were $43 \%$ higher that those of similarly qualified females in the same sectors and jobs. The ideology of male superiority was a system of beliefs that set a male standard, which became the yardstick with which women were judged when they entered male-dominated posts. They were set up for failure, blamed for any failures and through this process the myth that women were failures and that males were superior was reinforced (Mdladlana, 1999a). Mallon and Cassell (1999) referred to a British research study conducted to investigate women's perceptions of helping and hindering factors to their career development. Four themes emerged from the study (also supported by Jackson, 2001), namely:

- The culture and values of the organization, based on the male career model (long hours and total availability);

- Family care responsibilities and the organisation attitude to it (children have a negative impact on career progression);

- Lack of training and breadth of skill (lack of credible performance management system and lack of mentorship); and

- Lack of self-confidence (stems from the need to balance home and work in an unsupportive environment and a feeling of inadequacy in both). 
It seemed that many women, approaching the top of the corporate ladder, abandoned it. Jackson (2001) supported this notion. Frustration and disillusionment fuelled the perceptions of women. So, the glass ceiling still remained. The term "glass ceiling" indicated those invisible barriers that kept women from rising above a certain level in organisations (Jackson, 2001). It seemed that gender discrimination was so deeply embedded in organisational life that it was nearly invisible -systemic discrimination (Cassell, 1996). Bilineria in Burke and Mattis (2000) noted that even when women do all the right things and had the right competencies; they were still blocked from the inner most circles of power - corporate board level.

New models were needed to support the career psychology of women. Women should not be promoted in traditional ways but alternative models of leadership should be developed to suit the unique environment, skills and abilities of women (Humphries \& Grice, 1995). It seemed internationally that the Equal Employment Opportunity legislation had not worked that well. Legislation had brought the discrimination to the fore, but cannot curb systemic discrimination. In South Africa, the Employment Equity Act was seen as a tool to ensure the upward mobility of women in the labour market and to break the glass ceiling that had prevented women from growing and having the same access to job opportunities as their male counterparts (Mdladlana, 1999a).

Would South Africa fare any better? Dickens (1994) predicted that the projected labour force between 1994 and 2006 would be 1,5 million of which 1,3 million would be female. Women with children will constitute a major component of labour supply. It is argued that women could no longer be treated as second-class workers. Employers would need to recognise career ambitions and domestic responsibilities.

The only way to know how organisations would fare is by means of an employment equity audit. However, there still may be a possibility that an instrument used for assessing employment equity could still be biased and thereby further entrenching gender discrimination.

Against the background of the above-mentioned discussion the primary objective of this study was to determine whether there were gender differences with regard to perceptions on employment equity practices.

A secondary objective of the study was to assess whether any items in the employment equity instrument were biased based on gender stereotypes.

\section{METHOD}

Sample

A sample of convenience consisting of 4729 participants from various organisations across different industries such as the media, higher education, finances, chemical, motor manufacturing and IT.

The sample of convenience ranged between 24 years and 51 years of age with the biggest concentration in the 25-30 year age group. Of the sample group, $33,5 \%$ were Black, $10,4 \%$ were Coloured, $3,8 \%$ were Indian and $52,2 \%$ were White. In the total sample $49,4 \%$ were male and $50,6 \%$ were female. (See Table 1 ).

\section{Instrument}

A 134-item Employment Equity Questionnaire developed by Martins (1999) was used, based on the employment equity process. Only 41 items were included in this study, as those items were generic across all nine companies representing different industries. Examples of some of the items were:

- "I know what Employment Equity is about";

- "In the company all people have the same opportunities for promotion";
- "Affirmative actions placements should be linked to the availability of vacant positions in the company"; and

- "In the company employees are encouraged to use/develop their own abilities and to improve them further".

\section{TABLE 1}

BIOGRAPHICAL INFORMATION ON THE PARTICIPANTS

\begin{tabular}{cc}
\hline AGE & PERCENTAGE \\
\hline 24 years and younger & 14,2 \\
25-30 years & 19,2 \\
31-35 years & 13,9 \\
36-40 years & 14,5 \\
$41-45$ years & 15,5 \\
46-50 years & 11,0 \\
51 years and older & 11,6 \\
Total & 100,0 \\
RACE & PERCENTAGE \\
Black & 33,5 \\
Coloured & 10,4 \\
Indian & 3,8 \\
White & 52,2 \\
Total: 100,0 & \\
GENDER & PERCENTAGE \\
Male & 49,4 \\
Female & 50,8 \\
Total & 100,0 \\
\hline
\end{tabular}

The items were based on issues such as training, promotions, affirmative action, wages, labour law and general management and leadership issues. The questionnaire comprised of four sections where Section one to three required information on the employment equity process and Section four required biographical information. The response scales used for every item were categorical in nature and response categories were ranging from strongly disagree, disagree to agree and strongly agree. The medium used was English as all participants were comfortable with the language.

\section{Procedure}

The questionnaires were distributed amongst samples of convenience through contact persons in different organisations. All information was treated with confidentiality; and total anonymity was ensured, as identities of participants could not be traced in any way.

After completion the questionnaires were returned to the contact person in the particular organization and collected for further analysis. The data, in secondary form, were put to the avail of the current authors for research purposes.

\section{RESULTS}

Analysis of the data was conducted in two stages. The first stage was focused on the two levels of factor analyses in order to 'purify' the constructs and determine the reliability of the variables. The first stage is described in more detail below:

\section{First stage of the data analysis}

A two-level factor analysis was conducted to reduce the set of dimensions to more reasonable homogenous dimensions. On the first level, inter-correlations of the 41 items were executed first (this matrix is not displayed owing to a lack of space). A Kaiser-Meyer-Olkin (KMO) test of sampling adequacy was 
executed on the inter-correlation matrix and a highly acceptable coefficient of 0,976 was obtained. A Bartlett's test of sphericity was also executed and yielded a Chi-Square of $100624,4(p=0,000)$. These values indicated that the item inter-correlation matrix was suitable for further factor analysis.

Eigenvalues of the unreduced item inter-correlation matrix were calculated and a number of factors were postulated based on Kaiser's (1961) criterion. According to Table 2 five factors were postulated and they account for about $54 \%$ of the variance in the factor space.

TABLE 2

EIGENVALUES OF THE UNREDUCED ITEM INTER-CORRELATION MATRIX

\begin{tabular}{|c|c|c|c|}
\hline \multicolumn{4}{|c|}{ Initial Eigenvalues } \\
\hline Root & Eigenvalues & $\%$ of variance & $\%$ Cumulative variance \\
\hline 1 & 16,125 & 39,329 & 39,329 \\
\hline 2 & 2,145 & 5,232 & 44,561 \\
\hline 3 & 1,485 & 3,623 & 48,184 \\
\hline 4 & 1,152 & 2,809 & 50,993 \\
\hline 5 & 1,133 & 2,763 & 53,756 \\
\hline 6 & 0,994 & 2,425 & 56,181 \\
\hline 7 & 0,916 & 2,234 & 58,415 \\
\hline 8 & 0,902 & 2,199 & 60,613 \\
\hline 9 & 0,827 & 2,018 & 62,632 \\
\hline 10 & 0,819 & 1,997 & 64,629 \\
\hline 11 & 0,783 & 1,910 & 66,639 \\
\hline 12 & 0,706 & 1,723 & 68,262 \\
\hline 13 & 0,697 & 1,701 & 69,963 \\
\hline 14 & 0,667 & 1,628 & 71,591 \\
\hline 15 & 0,636 & 1,551 & 73,142 \\
\hline 16 & 0,627 & 1,629 & 74,671 \\
\hline 17 & 0,591 & 1,442 & 76,113 \\
\hline 18 & 0,585 & 1,428 & 77,641 \\
\hline 18 & 0,551 & 1,344 & 78,884 \\
\hline 20 & 0,549 & 1,340 & 80,225 \\
\hline 21 & 0,539 & 1,316 & 81,640 \\
\hline 22 & 0,487 & 1,189 & 82,729 \\
\hline 23 & 0,476 & 1,161 & 83,890 \\
\hline 24 & 0,461 & 1,125 & 85,015 \\
\hline 25 & 0,452 & 1,101 & 86,117 \\
\hline 26 & 0,447 & 1,091 & 87,208 \\
\hline 27 & 0,435 & 1,061 & 88,269 \\
\hline 28 & 0,417 & 1,016 & 89,285 \\
\hline 29 & 0,411 & 1,002 & 90,287 \\
\hline 30 & 0,402 & 0,980 & 91,267 \\
\hline 31 & 0,393 & 0,958 & 92,225 \\
\hline 32 & 0,378 & 0,922 & 93,147 \\
\hline 33 & 0,372 & 0,907 & 94,053 \\
\hline 34 & 0,363 & 0,886 & 94,938 \\
\hline 35 & 0,339 & 0,826 & 95,764 \\
\hline 36 & 0,337 & 0,821 & 96,686 \\
\hline 37 & 0,318 & 0,776 & 97,360 \\
\hline 38 & 0,304 & 0,742 & 98,102 \\
\hline 39 & 0,276 & 0,673 & 98,775 \\
\hline 40 & 0,265 & 0,646 & 99,421 \\
\hline 41 & 0,237 & 0,579 & 100,000 \\
\hline
\end{tabular}

Trace $=41$

Principal Axis factoring was used to generate a sorted and rotated factor matrix and the respective item-loadings on each postulated factor are reflected in Table 3 .
TABLE 3

SORTED AND ROTATED FACTOR MATRIX OF THE FIRST LEVEL FACTOR ANALYSIS

\begin{tabular}{|c|c|c|c|c|c|}
\hline \multirow[b]{2}{*}{ ITEM } & \multicolumn{5}{|c|}{ FACTOR } \\
\hline & 1 & 2 & 3 & 4 & 5 \\
\hline 4 & 0,715 & & & & \\
\hline 30 & 0,663 & & & & \\
\hline 26 & 0,652 & & & & \\
\hline 29 & 0,646 & & & & \\
\hline 35 & 0,615 & 0,342 & & & \\
\hline 14 & 0,614 & & & & \\
\hline 10 & 0,602 & & & & \\
\hline 33 & 0,597 & & & & \\
\hline 36 & 0,695 & & & 0,310 & \\
\hline 16 & 0,688 & 0,335 & & & \\
\hline 25 & 0,640 & 0,360 & & & \\
\hline 31 & 0,639 & 0,404 & & & \\
\hline 7 & 0,481 & & 0,368 & & \\
\hline 13 & 0,465 & & 0,335 & 0,351 & \\
\hline 18 & 0,445 & & 0,359 & 0,323 & \\
\hline 6 & 0,443 & 0,414 & 0,338 & & \\
\hline 38 & 0,405 & & 0,367 & & \\
\hline 20 & 0,399 & 0,371 & & & \\
\hline 28 & 0,350 & & & & \\
\hline 3 & & 0,632 & & & \\
\hline 11 & 0,492 & 0,623 & & & \\
\hline 19 & 0,429 & 0,609 & & & \\
\hline 21 & 0,330 & 0,600 & & & \\
\hline 5 & & 0,552 & & & \\
\hline 41 & 0,488 & 0,495 & 0,354 & & \\
\hline 8 & 0,448 & 0,479 & & & \\
\hline 23 & & 0,352 & & & \\
\hline 4 & & 0,331 & & & \\
\hline 37 & 0,333 & & 0,646 & & \\
\hline 27 & 0,399 & & 0,522 & & \\
\hline 32 & 0,392 & 0,380 & 0,499 & & \\
\hline 24 & 0,384 & & 0,485 & & \\
\hline 1 & & & & 0,631 & \\
\hline 12 & & & & 0,511 & \\
\hline 34 & & & & 0,412 & \\
\hline 2 & & & & 0,399 & \\
\hline 39 & 0,307 & & & 0,358 & \\
\hline 40 & & & & 0,345 & \\
\hline 17 & & & & 0,288 & \\
\hline 15 & & & & 0,335 & 0,697 \\
\hline 22 & & & & & 0,607 \\
\hline
\end{tabular}

Hereafter, sub-scores were calculated on all the postulated factors and they were inter-correlated. The inter-correlations $(5 \times 5)$ of these sub-scores are presented in Table 4 and one can infer that all inter-correlations are significant on the 0,01 level.

Before the second level factor analysis was continued, a KMO measure of sampling adequacy was executed which yielded a coefficient of 0,813 . The Bartlett's test of sphericity yielded a Chi-Square of $12985,91(\mathrm{p}=0,000)$. The intercorrelation matrix of sub-scores was also suitable for further factor analysis.

Eigenvalues were again calculated on the unreduced intercorrelation matrix and a number of factors postulated according to Kaiser's (1961) criterion. As can be inferred from Table 5, only one factor was postulated which explains about $64 \%$ variance in the factor space. 
TABLE 4

INTER-CORRELATION OF SUBSCORES (sS)

\begin{tabular}{llllll}
\hline & SS1 & SS2 & SS3 & SS4 & SS5 \\
\hline SS1 & 1 & 0,812 & 0,783 & 0,564 & 0,381 \\
SS2 & 0,812 & 1 & 0,707 & 0,522 & 0,326 \\
SS3 & 0,783 & 0,707 & 1 & 0,471 & 0,329 \\
SS4 & 0,564 & 0,522 & 0,471 & 1 & 0,473 \\
SS5 & 0,381 & 0,326 & 0,329 & 0,473 & 1 \\
\hline
\end{tabular}

All correlations are significant at the 0,01 level.

TABLE 5

EIGENVALUES OF THE UNREDUCED INTER-CORRELATION MATRIX OF SUBSCORES

\begin{tabular}{lccc}
\hline \multicolumn{3}{c}{ Initial Eigenvalues } \\
\hline Root & Eigenvalues & \% of variance & \% Cumulative variance \\
1 & 3,202 & 64,048 & 64,048 \\
2 & 0,868 & 17,162 & 81,210 \\
3 & 0,483 & 9,662 & 90,871 \\
4 & 0,290 & 6,803 & 96,674 \\
5 & 0,166 & 3,326 & 100,000 \\
\hline
\end{tabular}

Trace $=5$

The factor-loadings of the sub-scores on the obtained, single scale are presented in Table 6.

TABLE 6

FACTOR LOADINGS OF SUBSCORES

\begin{tabular}{lll}
\hline & FACTOR $\mathbf{1}$ & $\mathbf{h}^{2} \mathbf{j}$ \\
\hline SS1 & 0,934 & 0,872 \\
SS2 & 0,847 & 0,717 \\
SS3 & 0,808 & 0,653 \\
SS4 & 0,639 & 0,408 \\
SS5 & 0,453 & 0,205 \\
\hline
\end{tabular}

Subsequently, a reliability analysis was conducted on this single scale and this yielded a coefficient Alpha of 0,9593. The item statistics on this scale are reflected in Table 7 . These analyses conclude the first stage of the analysis and suggest that the scale used for further analyses, is sufficiently reliable.

The second stage of the data analysis

The second stage of the analysis was conducted to test if there were any significant differences between gender groups with regard to perceptions on employment equity practices. An ANOVA was conducted for this purpose and the results are portrayed in Table 8 .

The results from Table 8 suggest that there are significant gender differences with regard to overall perceptions on employment equity practices. However, if the effects of unequal sample sizes are partialled out, only $4,1 \%$ of the variance can be attributed to differences in perceptions on employment equity practices. The proportion of variance explained, is practically insignificant and the discriminant validity of the Employment Equity Questionnaire (this refers to the 41 items and not the item pool of 134 in the Employment Equity questionnaire) can therefore be questioned.
TABLE 7

ITEM STATISTICS AND RELIABILITY ANALYSIS OF EMPLOYMENT EQUITY INSTRUMENT

\begin{tabular}{|c|c|c|c|c|}
\hline Item & $\begin{array}{l}\text { Scale mean if } \\
\text { item deleted }\end{array}$ & $\begin{array}{l}\text { Scale variance if } \\
\text { item deleted }\end{array}$ & $\begin{array}{l}\text { Corrected item } \\
\text { total correlation }\end{array}$ & $\begin{array}{l}\text { Alpha if } \\
\text { item deleted }\end{array}$ \\
\hline 6 & 110,6900 & 389,2829 & 0,4414 & 0,9591 \\
\hline 84 & 110,4181 & 393,0069 & 0,3233 & 0,9597 \\
\hline 12 & 110,4379 & 383,1696 & 0,6517 & 0,9580 \\
\hline 11 & 110,4726 & 387,7620 & 0,5353 & 0,9586 \\
\hline 4 & 110,2068 & 383,7499 & 0,6274 & 0,9581 \\
\hline 1 & 110,4441 & 380,5236 & 0,6648 & 0,9579 \\
\hline 7 & 110,7951 & 379,4629 & 0,6817 & 0,9578 \\
\hline 8 & 110,6786 & 382,7871 & 0,6068 & 0,9582 \\
\hline 10 & 110,7568 & 378,8258 & 0,7497 & 0,9574 \\
\hline 14 & 110,4944 & 380,7458 & 0,7164 & 0,9576 \\
\hline 15 & 110,0340 & 380,5041 & 0,6419 & 0,9580 \\
\hline 16 & 110,3698 & 392,2581 & 0,4280 & 0,9591 \\
\hline 17 & 110,7720 & 379,8660 & 0,6734 & 0,9578 \\
\hline 19 & 110,7111 & 379,4648 & 0,7136 & 0,9576 \\
\hline 20 & 110,0406 & 394,9345 & 0,2957 & 0,9597 \\
\hline 26 & 110,6481 & 380,0788 & 0,7050 & 0,9577 \\
\hline 27 & 110,2502 & 394,1369 & 0,3177 & 0,9597 \\
\hline 30 & 110,4836 & 383,3318 & 0,6800 & 0,9579 \\
\hline 32 & 110,5094 & 384,9957 & 0,6369 & 0,9581 \\
\hline 34 & 110,4864 & 384,4673 & 0,6642 & 0,9580 \\
\hline 37 & 110,4699 & 384,0351 & 0,6298 & 0,9581 \\
\hline 38 & 110,5227 & 392,7690 & 0,3399 & 0,9596 \\
\hline 76 & 110,5991 & 384,5638 & 0,5970 & 0,9583 \\
\hline 41 & 110,3075 & 390,5319 & 0,4584 & 0,9590 \\
\hline 45 & 110,6572 & 381,4296 & 0,6961 & 0,9577 \\
\hline 46 & 110,6164 & 380,9882 & 0,7331 & 0,9576 \\
\hline 94 & 110,5331 & 388,8289 & 0,5050 & 0,9587 \\
\hline 48 & 110,5931 & 383,3632 & 0,6533 & 0,9580 \\
\hline 54 & 110,7583 & 379,1194 & 0,7121 & 0,9576 \\
\hline 55 & 110,6669 & 379,9185 & 0,7328 & 0,9575 \\
\hline 56 & 110,5342 & 382,0708 & 0,6857 & 0,9578 \\
\hline 57 & 110,5580 & 389,1845 & 0,4773 & 0,9589 \\
\hline 58 & 110,7585 & 379,9451 & 0,7101 & 0,9576 \\
\hline 59 & 110,2692 & 392,0889 & 0,4150 & 0,9592 \\
\hline 60 & 110,5743 & 380,0347 & 0,7158 & 0,9576 \\
\hline 63 & 110,6746 & 380,9480 & 0,7117 & 0,9577 \\
\hline 65 & 110,0459 & 385,7938 & 0,5097 & 0,9588 \\
\hline 71 & 110,4974 & 381,7204 & 0,6684 & 0,9579 \\
\hline 81 & 110,3605 & 393,7319 & 0,3895 & 0,9592 \\
\hline 82 & 110,3866 & 393,2600 & 0,3951 & 0,9592 \\
\hline 9 & 110,6976 & 383,7766 & 0,6120 & 0,9582 \\
\hline
\end{tabular}

ALPHA $=0,9593$

The fact that there are significant gender differences, takes the analysis one step further where the focus is on gender differences on an item level. Cramer's V was applied in this analysis and note should be taken that some differences (5\%) on this level may be purely attributable to chance. Results as displayed in Table 9, should therefore be interpreted with caution. All the Cramer's V coefficients are statistically significant.

All the items were scrutinised for stereotypical wording, to ensure that obtained response patterns were based on perceptual differences and not as a response to the wording of items. No item wordings could be detected that might have contributed to gender differences. 
TABLE 8

ANOVA: COMPARING OVERALL MEAN SCORES ON GENDER PERCEPTIONS

\begin{tabular}{|c|c|c|c|c|c|c|}
\hline GENDER & & MEAN & & $\begin{array}{l}\text { STD. } \\
\text { DEVIATION }\end{array}$ & & $\mathbf{N}$ \\
\hline MALE & & 2,7292 & & 0,51452 & & 2296 \\
\hline FEMALE & & 2,9122 & & 0,35784 & & 2349 \\
\hline TOTAL & & 2,8217 & & 0,45160 & & 4645 \\
\hline SOURCE & $\begin{array}{l}\text { TYPE III } \\
\text { SUM OF } \\
\text { SQUARES }\end{array}$ & Df & $\begin{array}{l}\text { MEAN } \\
\text { SQUARE }\end{array}$ & F-RATIO & $\mathrm{F}(\mathrm{P})$ & $\begin{array}{l}\text { PARTIAL } \\
\text { ETA } \\
\text { SQUARED }\end{array}$ \\
\hline $\begin{array}{l}\text { CORRECTED } \\
\text { MODEL }\end{array}$ & 38,901 & 1 & 38,901 & 198,868 & 0,000 & 0,041 \\
\hline $\begin{array}{l}\text { INTERCEPT } \\
0,976\end{array}$ & 36952,38 & 1 & 36952,4 & \multicolumn{2}{|l|}{188907,116} & 0,000 \\
\hline GENDER & 38,901 & 1 & 38,901 & 198,868 & 0,000 & 0,041 \\
\hline ERROR & 908,224 & 4643 & 0,196 & & & \\
\hline TOTAL & 37931,69 & 4645 & & & & \\
\hline $\begin{array}{l}\text { CORRECTED } \\
\text { TOTAL }\end{array}$ & 947,124 & 4644 & & & & \\
\hline
\end{tabular}

R SQUARED = 0,041 (ADJUSTED R SQUARED - 0,041)

TABLE 9

Cramer's V TEST ON ITEM LEVEL

\begin{tabular}{|c|c|c|}
\hline ITEM & CRAMER'S V & SIG (P) \\
\hline 1 & 0,108 & 0,000 \\
\hline 2 & 0,200 & 0,000 \\
\hline 3 & 0,220 & 0,000 \\
\hline 4 & 0,123 & 0,000 \\
\hline 5 & 0,153 & 0,000 \\
\hline 6 & 0,197 & 0,000 \\
\hline 7 & 0,183 & 0,000 \\
\hline 8 & 0,212 & 0,000 \\
\hline 9 & 0,241 & 0,000 \\
\hline 10 & 0,254 & 0,000 \\
\hline 11 & 0,179 & 0,000 \\
\hline 12 & 0,124 & 0,000 \\
\hline 13 & 0,231 & 0,000 \\
\hline 14 & 0,189 & 0,000 \\
\hline 15 & 0,162 & 0,000 \\
\hline 16 & 0,248 & 0,000 \\
\hline 17 & 0,171 & 0,000 \\
\hline 18 & 0,221 & 0,000 \\
\hline 19 & 0,234 & 0,000 \\
\hline 20 & 0,277 & 0,000 \\
\hline 21 & 0,211 & 0,000 \\
\hline 22 & 0,201 & 0,000 \\
\hline 23 & 0,218 & 0,000 \\
\hline 24 & 0,120 & 0,000 \\
\hline 25 & 0,260 & 0,000 \\
\hline 26 & 0,253 & 0,000 \\
\hline 27 & 0,246 & 0,000 \\
\hline 28 & 0,271 & 0,000 \\
\hline 29 & 0,244 & 0,000 \\
\hline 30 & 0,264 & 0,000 \\
\hline 31 & 0,242 & 0,000 \\
\hline 32 & 0,178 & 0,000 \\
\hline 33 & 0,237 & 0,000 \\
\hline 34 & 0,193 & 0,000 \\
\hline 35 & 0,266 & 0,000 \\
\hline 36 & 0,274 & 0,000 \\
\hline 37 & 0,095 & 0,000 \\
\hline 38 & 0,207 & 0,000 \\
\hline 39 & 0,197 & 0,000 \\
\hline 40 & 0,167 & 0,000 \\
\hline 41 & 0,199 & 0,000 \\
\hline
\end{tabular}

A cut-off value of 0,240 was applied to select the top $30 \%$ of the items. These 12 items are printed in bold and may reflect the employment equity practices where gender differences are the greatest. Gender differences on these items will be discussed in more detail below:

Item 9 stated that managers and supervisors are good leaders. Females $(61,0 \%)$ experienced this issue more positively than their male counterparts $(42,6 \%) .20,6 \%$ of males strongly disagreed while only $6,2 \%$ of females strongly disagreed. Item 10 stated that management has the leadership to take the company successfully beyond the year 2000 . Females $(68,2 \%)$ agreed while males $(50,0 \%)$ agreed. But again $14,4 \%$ of males strongly disagreed while only $3,2 \%$ of females strongly disagreed. Item 16 stated that the company cares for its employees. Females $(67,7 \%)$ agreed, while males $(47,3 \%)$ agreed. Again males (20,3\%) disagreed strongly as opposed to females $(5,8 \%)$ who disagreed strongly. Items 25 and 26 dealt with issues pertaining the support the company renders towards training and development. Females $(70,6 \%)$ were more positive with regards to the company's monetary contribution with their training as opposed to males $(48,8 \%)$. However males $(18,3 \%)$ disagreed more strongly than females $(5,2 \%)$. Females $(59,8 \%)$ also indicated that their supervisors knew their training needs; whereas males $(44,8 \%)$ agreed. However $19,0 \%$ of males strongly disagreed as opposed to $6,5 \%$ of females. On item 27 that dealt with the issue whether affirmative action is justified both male $(55,1 \%)$ and female $(76,5 \%)$ agreed, but again males $(12,5 \%)$ disagreed more strongly than females $(3,0 \%)$. On item 28 , females $(74,1 \%)$ and males $(52,9 \%)$ agreed that relationships between different racial groups within their companies are good. Yet again males $(17,7 \%)$ disagreed more strongly than females $(3,3 \%)$. On item 29 with regards to promotional issues males $(42,7 \%)$ and females $(61,6 \%)$ agreed that the most capable employees, irrespective of gender or race are selected for promotion. However males $(23,3 \%)$ disagreed more strongly as well as opposed to females $(7,5 \%)$. Item 30 stated that the company is doing what it says regarding equal opportunities for all race groups, males $(50,0 \%)$ and females $(70,6 \%)$ agreed; but males $(20,9 \%)$ disagreed more strongly than females $(5,0 \%)$. Item 31 stated that training programmes are available to help employees improve their skills to be promoted to higher positions in the company. Females $(70,6 \%)$ reacted more positively than their male counterparts $(51,6 \%)$. Males $(15,4 \%)$ disagreed more strongly than the females $(3,4 \%)$. On item 35 whether the participants did not feel discriminated against by the company, both male $(50,0 \%)$ and female $(71,0 \%)$ agreed. Again males $(19,4 \%)$ disagreed more strongly than females $(4,6 \%)$. On item 36 , females $(70,2 \%)$ agreed that the company is managed effectively, whereas males $(46,6 \%)$ agreed. Males $(18,9 \%)$ disagreed more strongly than the females $(4,8 \%)$.

\section{DISCUSSION}

The primary purpose of the study was to determine if there were gender differences with regard to perceptions on employment equity practices. The results of the ANOVA indicated that there were significant differences, although the proportion of variance explained was small. Overall, females experienced the employment equity practices more positive than males, as reflected by their higher mean score. The results indicate that the Employment Equity Questionnaire possesses some discriminant validity. With this finding the main objective of the study was achieved.

The secondary objective of the study was to assess if any items in the employment equity instrument were biased on gender stereotypical grounds. Although Cramer's V detected significant differences on all the items, no specific wording of any item reflected a negative stereotype towards gender groups. 
It can be concluded that the items are not biased towards gender groups. With this finding the secondary objective of the study was also achieved.

A further scrutiny of 10 of the 12 items that yielded the highest Cramer's V coefficients, served as a basis for identifying the employment equity issues females and males differ most on. These items suggested that females perceived the leadership in their companies in a more positive light than their male counterparts. Females also experienced the companies to be more caring. Females perceived their companies to be more supportive with regards to training and development as well as creating the environment to use the skills obtained as opposed to the male participants. In the literature review it became apparent that women indicated the opportunity for training and development as one of the usual barriers to their progression (Mallon \& Cassell, 1999). The results however indicated the opposite where females perceived that their companies gave them support and opportunities In this regard. Females indicated that they also believe that the training and development will assist employees in achieving higher positions. Females indicated that they do not feel discriminated against and that they believe that the best candidate will be selected for promotions irrespective of gender or race. This position gives companies a good starting point.

As stated earlier it seemed that females perceive the employment equity issues that were addressed in the audit as more positive than their male counterparts. Although the general trend was to agree with the items, the female mean scores were generally higher than those of their male counterparts. It could be argued that females perceive the employment equity legislation as a tool by government to enforce equal opportunities.

It is however, important to reflect a few cautionary thoughts on item construction that can further improve the discriminant validity of the questionnaire. More specifically, items should be unidirectional in meaning. Items in the audit skimmed broad concepts reflective of employment equity issues such as race, gender, religion, language, etc. These issues were mostly grouped together when addressed in a particular item. This could have had an impact on the item responses, as it is not known on which issue the respondent might have focussed as the leading issue. This recommendation must also be seen in the context of the 41 items used as the overall model and dimension construction of the 134 items were not included in this study.

It is argued that the legislation pertaining to employment equity practices raised awareness of direct and indirect discriminatory practices. Issues such as flexibility towards working women and child-rearing also addressed some of the issues that women globally raised as concerns (Mdladlana, 1999a). However, systemic discrimination is deeply rooted not only in practices and procedures but in attitudes as well e.g. the male models of management and leadership as indicated by the British research study (Mallon \& Cassell, 1999). In this sense an employment equity audit could be biased, because it does not drill down deep enough to bring these systemic discriminatory perceptions to the fore. It is also argued that employment equity alone will not change systemic discrimination. Literature (Jackson, 2001) showed that a large number of women who have successfully climbed the corporate ladder disembark because the stereotyping (and systemic discrimination) is too powerful at the top.

The greatest limitation of the study is perhaps the fact that samples of convenience were used in all the companies from the different industries. Findings can only be generalised to these companies, and not to other companies or to the wider industry as such.
Suggestions for further research are focused on the improvement on the Employment Equity Questionnaire. Attention must be given to item format and the response scale format specifically. Care needs to be taken that items cover all the domains of the specified construct sufficiently. Items should preferably be in question format and should also avoid common pitfalls of item formulation. Response scale formats should be changed to five-point intensity scales where only the extreme poles are anchored.

\section{The implications for companies}

It is important to note that true change does not only start in companies. It must start much earlier on - that is the way both male and female children are brought up. It is with early upbringing that stereotyping takes root. With that much said, however, companies now have the responsibility to eradicate systemic discrimination. Companies should scrutinize their cultures to make sure that the dominant career model is not only based on the male perception of career success. Companies should strive to achieve a fair balance between career planning opportunities and domestic responsibilities for women. Appropriate mentorship schemes for women should facilitate the above process. These mentors should be female role models. This will mean that companies need to relook the average positions of women in their companies and their responsibilities. This should also facilitate the building of visible leadership models that are appropriate to women. Companies must also ensure that their employment equity programmes move beyond the numbers game and truly embraces diversity and that it pays attention to gender issues.

Is the glass ceiling cracking? Employment equity brought about visible cracks in the ceiling of male dominance, and women today are quite aware of these cracks. But there are still not enough women crawling through the cracks to put a positive end to a topic that has been discussed since 1963 .

\section{ACKNOWLEDGEMENT}

The authors are indebted to Prof Nico Martins of Organisational Diagnostics for providing the data set for conducting this research. The 41-item EEQ used in this research was abstracted from a larger item pool collected across various organisations and does not constitute the original Employment Equity Audit of Prof Martins. Data collected from each organisation by means of the Survey was suplemented by qualitative methods.

The authors would like to thank Riëtte Eiselen and her staff from Statcon at RAU for their professional service and valuable contribution regarding the data analysis for this project.

\section{REFERENCES}

Adams, C. (Ed). (1993). Affirmative Action in a Democratic South Africa. Juta: Kenwyn

Burke, J.R. \& Mattis, M.C. (Ed). (2000). Women on Corporate Boards of Directors. International Challenges and Opportunities. Kluwer Academic Publishers: Dordrecht.

Coates, G. (1997). Organisation Man - Women and organisational Culture. Sociological Research Online. Vol. 2 No 3. Retrieved from the Word Wide Web on 21 June 1999: http://www.socresonline.org.uk

Davidson, M.J. \& Cooper, C.L. (1992). Shattering the Glass Ceiling. The Woman Manager. Paul Chapman Publishing: London

Dickens, L. (1994). The Business Case for Women's Equality. Employee Relations, 16 (8). 5-18.

Ellman, S.E. (1963). Managing Women in Business. Prentice-Hall: Connecticut.

Human, L. (1996). Managing Workforce Diversity: a critique and example from South Africa. International Journal of Manpower, 17 (4/5), 46-64. 
Human Resources Development Canada. (1996). New Employment Equity Act and Regulations Strengthen Canadian Workplace. Retrieved from the World Wide Web on 23 August 2002: http://labour-travail.hrdc-drhc.gc.ca.

Humphries, M. \& Grice, S. (1996). Equal Employment Opportunity and the Management of Diversity. Journal of Organizational Change Management, 8 (5), 17-32.

Jackson, J.C. (2001). Women middle Managers' perception of the Glass Ceiling. Women in Management Review, 16 (1), 30-41.

Mallon, M. \& Cassell, C. (1999). What do Women Want? The Journal of Management Development, 18 (2). 137-154.

Martins, N. (1999). Questionnaire on Employment Equity. Unpublished document.

Mavin, S. (2001). Women's Career in Theory and Practice: time for Change? Women in Management Review, 16 (4), 183-192.

Mdladlana, M. (1999a). Address: Launch of the Commission For EE and Chapter 2 of the Employment Equity Act. Retrieved from the
World Wide Web on 23 August 2002: http://www.labour.gov.za Mdladlana, M. (1999b). Speech: Media launch of the Chapter 3 of the Employment Equity Act. Retrieved from the World Wide Web on 23 August 2002:http://www.labour.gov.za

Meyerson, D.E. \& Fletcher, J.K. (2000). A Modest Manifesto for Shattering the Glass Ceiling. Harvard Business Review. JanFeb, 127-136.

Sinclair, A. (2000). Women within Diversity: risks and possibilities. Women in Management Review, 15 (5/6), 237246.

Thomas, A. (1997). Beyond Affirmative Action. Knowledge Resources: Randburg.

Thomas, A. (2002). Employment Equity in South Africa: lessons from the global world. International Journal of Manpower, 23 (3), 237-255.

Toumishey, S.J. (2001). Most Frequently Asked Employment Equity Questions. Retrieved from the World Wide Web on 23 August 2002. http://is.dal.ca/ eeequity/INFO/ question.htm 